\title{
Methodological View of Business Ethics Researches in Turkey: A Review on Postgraduate Theses
}

\author{
Sevdiye E. Y1lmaz ${ }^{1}$ \\ ${ }^{1}$ Department of International Trade, Cankiri Karatekin University, Cankiri, Turkey \\ Correspondence: Sevdiye E. Y1lmaz, Department of International Trade, Cankiri Karatekin University, Cankiri, \\ Turkey.
}

Received: June 24, 2019

Accepted: July 9, 2019 Online Published: July 22, 2019

doi:10.5539/ibr.v12n8p107

URL: https://doi.org/10.5539/ibr.v12n8p107

\begin{abstract}
This study was designed with an aim to search for an answer to the question what is the current situation of the studies conducted on business ethics in the business management literature in Turkey. Within the scope of the study, 81 postgraduate theses prepared in the field of business management were examined in terms of methodology. In the analysis, it was seen that the majority of the theses were quantitative studies using the survey method as the data acquisition method. As a result of the analyses performed, it was detected that the theses on business ethics in Turkey shaped under the domination of positivist paradigm methodologically. However, most of the postgraduate theses were carried out in a superficial context, neglecting the requirements of positivist paradigm. In line with the findings obtained, it was concluded that the majority of the postgraduate theses on business ethics in Turkey were superficial studies ignoring the complicated nature of business ethics.
\end{abstract}

Keywords: ethics, business ethics, thesis

\section{Introduction}

Business ethics is a discipline drawing intense interest academically. In addition, the methodological reviews of the academic studies conducted in the field of business ethics are frequently encountered especially in the foreign literature. These studies demonstrate that business ethics exhibits a multidisciplinary structure explicitly. Accordingly, business ethics is at the intersection of various disciplines such as economics, management sciences, sociology, organizational psychology and philosophy (Buckley, 2013; Brand, 2009). Probably for this reason, there is not a research methodology shared by researchers or in harmony with each other in the field of business ethics (Brand, 2009:429). Each discipline that conducts research on the subject shapes research questions and research methodology within the framework of its specialty (Buckley, 2013:695). It is seen that business management researchers prefer quantitative methodologies to a large extent in accordance with their academic background. Research using qualitative methodologies such as in-depth interviews is relatively few. (Lock \& Seele, 2015; Brand, 2009; Brand \& Slater, 2003; McDonald, 2000; Cowton, 1998). In this respect, it is possible to say that the researches of business ethics, which mainly focus on quantitative methodologies, are shaped within the framework of positivist paradigm. (Brand, 2009:431; Crane, 1999:237).

As can be seen, these studies conducted in order to reveal the methodological view of the researches in the field of business ethics in the foreign literature shed an important light on the subject. Nevertheless, it is difficult to state that there is enough effort in this direction in the domestic literature. Therefore, this research aims to contribute to the literature by examining the methodology of the studies conducted in the field of business ethics in the Turkish literature.

\section{Method}

"What is ethics?" The answer to this simple question consisting of three words is quite complex and difficult. So much so that ethics, which is an important branch of philosophy, can follow its roots at least 2500 years back, but still seeks the answer to this question (Treviño \& Brown, 2004; Brickley, Smith Jr. \& Zimmerman, 2002, Buckley et al., 2001). Ethics, in its most basic meaning, can be defined as the personal beliefs about what is right and wrong or what is good and bad (Fisher, 2004). Ethical philosophy basically focuses on how people should behave and the limits of right and wrong (Buckley et al., 2001:12). However, despite the considerable efforts of the greatest minds of the history such as Socrates, Plato and Aristotle, no consensus has been achieved on what 
ethical and unethical behaviours are (Brickley et al., 2002:1822). In contrast, approaches that have been put forward throughout the long history of the ethical philosophy often contradict each other on issues such as the nature of ethical behaviour, ethical dilemmas, and solutions (Treviño \& Brown, 2004:69). Therefore, the nature of ethical behaviour is still a topic far from being clarified. However, it is seen that philosophers, who are in disagreement about the nature of ethical behaviour, are largely in agreement on the purpose of ethics. Accordingly, the purpose of ethics is to enable the elimination or reduction of the damages caused by the abuse of power in people's daily lives. Thus, although ethics cannot make the lives of people perfect like in a fictional world, it can eliminate or reduce the possibility of being damaged.

Considering that ethics discusses human behaviours, it is not surprising that corporations are included in the study area of ethics. As a result, a corporation, in the most basic sense, is a collection of individuals with different and mostly conflicting interests (Brickley et al., 2002:1822). Nevertheless, the concept of business ethics cannot be claimed to have a long history in the academic context. In fact, although it is always difficult to determine exactly when a particular field of study emerges, it can be stated that business ethics is a very new field of study (Schwartz, 2007:43). Still, business ethics attracts much attention by academics and practitioners. In this context, business ethics has been the subject of many books, articles, seminars and conferences throughout its short history. However, despite all this boom of interest, business ethics remains a source of uncertainty for academics and practitioners. The inability to determine exactly what business ethics means lies at the bottom of this confusion. In other words, there is no universally accepted definition of business ethics (Robin, 2009; Randall \& Gibson, 1990; Vitell \& Festervand, 1987). This is not surprising considering that there is still no universally accepted definition of "ethics" despite its long history (Vitell \& Festervand, 1987:111). Of course, the effort to make such a definition that is universally accepted in the field of business ethics exceeds the scope of this study. However, conducting a study in the field of social sciences firstly requires defining these concepts at a certain level. Therefore, business ethics was defined within the scope this study as "the rules, codes or principles which provide guidelines for morally right behaviours in specific situations" (Lewis, 1985:383). Business ethics means more than virtue or honesty in business life. Accordingly, business ethics, which tries to explain the context, meaning and nature of business-related actions, is a discipline that focuses on what is morally right in the business world where ethical dilemmas are inevitable (Hoffman \& Moore, 1982; Lewis, 1985).

At first glance, it may be surprising that business ethics is a subject attracting intense attention of academicians and practitioners. As a matter of fact, it can be thought that enterprises will not have difficulty in determining the right and wrong actions in any situation. From this point of view, it can be argued that it is not necessary to attach great importance to business ethics since it will not be difficult to identify and exhibit ethical behaviours for enterprises. However, if there is a consensus among academicians on business ethics, it is that ethical decisions are not simple (Dimmock \& Fisher, 2017:143; Holme, 2008:250; Treviño \& Brown, 2004:70; Vitell \& Festervand, 1987:112; Lewis (1985:378). Treviño and Brown (2004) explain this situation by saying "rarely do decisions come with waving red flags that say 'Hey! I'm an ethical issue. Think about me in moral terms!'" (70). Therefore, it is certainly possible to say that the ethical issues that arise in the business world occur under specific circumstances and involve enormous complexities. This complex and challenging nature of business ethics stems from the fact that the decisions to be taken by enterprises are concern stakeholders that span a wide range of environment (employees, managers, customers, suppliers, shareholders, society) both inside and outside the enterprise (Dimmock \& Fisher, 2017). The possibility to exhibit unethical behaviour can manifest itself at all organizational levels (Lewis, 1985:378). However, the complex nature of these emerging situations prevents many managers or employees from identifying the right behaviour pattern. Therefore, Clegg, Kornberger and Rhodes (2007) defines business ethics as the process of continuous effort to make moral choices under conditions of severe and painful uncertainty (108). In order to reduce the uncertainties that may arise, it is necessary to determine the norms of ethical behaviour that should be applied in certain situations.

Business ethics practices of enterprises are often criticized for being superficial practices that are adopted for strategic purposes. So much so that, it is argued that business ethics is seen by enterprises as a means to gain more profit (Aasland, 2004:3-4). It is not so difficult to understand the reason for these criticisms considering that enterprises are profit-oriented organizations (Dimmock \& Fisher, 2017; Lewis, 1985). However, it may be wrong to say that business ethics is a tool that can only be used to increase profitability levels, even if it has positive effects on the profitability and efficiency of enterprises. According to Robin (2009), while the relationship between enterprises and ethics allows the enterprises to be managed effectively and efficiently, business ethics requires to minimize the losses that stakeholders may suffer (Robin, 2009:142). Indeed, the researchers show that business ethics practices adopted by enterprises have positive results for enterprises and stakeholders. Accordingly, it is stated that business ethics will increase the job satisfaction levels of employees 
and thus, the motivation levels of employees, who see that the values of the enterprise are in harmony with their own values, and their performances, which are an important determinant of customer satisfaction, will also increase (Holme, 2008:251). Business ethics is also an important factor in increasing the feeling of trust that connects managers, employees, shareholders, suppliers and customers with each other (Solomon, 2004; Buckley et al., 2001). Another important advantage of business ethics practices is that they provide employees with the necessary communication tools to inform the senior management about the unethical behaviours they perceive. In this way, enterprises have the opportunity to take measures against the situations that may put them into great trouble before they appear (Weavera \& Treviño, 2001:116).

In this context this study aims to conduct the methodological review of the postgraduate theses on business ethics in Turkey within the framework of certain criteria. The theses included in the study were accessed in April 2019 from the web page of the Council of Higher Education Thesis Centre (https://tez.yok.gov.tr/UlusalTezMerkezi/). In Turkey, business ethics and work ethics concepts are used in the same meaning both in the daily language and in the studies conducted in the field of business. Therefore, in the search made on the web page "business ethics" and "work ethics" keywords were used. On the thesis search page, 81 theses were found in the search made related to the theses having access permission and conducted in the field of business management. These 81 theses were examined within the framework of the predetermined criteria such as publication year, research questions type of study, data collection techniques in order to reveal the methodology of the studies. The findings were subjected to content analysis.

\section{Results}

When the theses on business ethics are examined, it is seen that most of them are master's theses. The number of $\mathrm{PhD}$ theses about business ethics is 10 . In this context, it can be stated that business ethics mostly attracts the attention of researchers at the master's degree. When we look at the findings in the table related to the years of publication of the examined theses, it is seen that business ethics has become a more popular topic for researchers in recent years. In the analyses performed, it was determined that the first study, which was accessible from the system related to the subject, was conducted in 1996. Between 1996 and 2006, there were only 4 postgraduate studies on business ethics. In other words, the subject did not attract the attention of researchers during a significant period of 10 years. Therefore, the recent increase of interest in business ethics can be considered as a remarkable finding.

Table 1. Findings Related to the Type and Publication Year of the Studies

\begin{tabular}{cccc}
\hline Variable & Category & Frequency & $\mathbf{\%}$ \\
\hline \multirow{2}{*}{ Type of Study } & Master's Thesis & 71 & 87.7 \\
& PhD Thesis & 10 & 12.3 \\
& Total & $\mathbf{8 1}$ & $\mathbf{1 0 0}$ \\
\hline \multirow{2}{*}{ Year of Publication } & 2018 & 12 & 14.8 \\
& 2017 & 8 & 9.9 \\
& 2014 & 7 & 8.6 \\
& 2009 & 7 & 8.6 \\
\hline
\end{tabular}

Table 2 presents the findings related to the most frequently searched answers in the theses. Accordingly, the most repetitive question is the "Is there a significant relationship between employee attitudes towards business ethics and demographic characteristics?" question. The researchers also tried to answer the question whether there is a relationship between business ethics and social responsibility, human resource management, job satisfaction, organizational commitment, employee performance and national culture. In this context, considering other findings that are not included in the table, it can be stated that business ethics is intensively investigated within the scope of organizational behaviour and human resources management. 
Table 2. Findings Related to the Research Questions

\begin{tabular}{|c|c|c|}
\hline Variable & Category & Frequency \\
\hline \multirow{8}{*}{ Research Question } & $\begin{array}{l}\text { Is there a significant relationship between the attitudes of employees } \\
\text { towards business ethics and demographic characteristics? }\end{array}$ & 41 \\
\hline & $\begin{array}{l}\text { Is there a significant relationship between business ethics and social } \\
\text { responsibility? }\end{array}$ & 14 \\
\hline & $\begin{array}{l}\text { Is there a significant relationship between human resources } \\
\text { management and business ethics? }\end{array}$ & 10 \\
\hline & $\begin{array}{l}\text { Is there a significant relationship between business ethics and job } \\
\text { satisfaction? }\end{array}$ & 8 \\
\hline & $\begin{array}{l}\text { Is there a significant relationship between the attitudes of employees } \\
\text { towards business ethics and organizational commitment? }\end{array}$ & 7 \\
\hline & $\begin{array}{l}\text { Is there a significant relationship between business ethics and } \\
\text { employee performance? }\end{array}$ & 6 \\
\hline & $\begin{array}{l}\text { Is there a significant relationship between business ethics and } \\
\text { national cultural dimensions? }\end{array}$ & 4 \\
\hline & Total & 90 \\
\hline
\end{tabular}

According to Table 3, almost all of the studies (91.4\%) are "empirical", and a small portion (8.6\%) is "conceptual". "Theoretical" study was not found. It was seen that $86.4 \%$ of the theses examined adopted "quantitative", and 6.8\% adopted "qualitative" method. In addition, $6.8 \%$ of them used quantitative and qualitative methods together and were "mixed" studies. Therefore, a large part of the postgraduate theses examined can be considered "quantitative" studies.

In $86.1 \%$ of the theses, most of which were conducted in the quantitative context, "questionnaire" was used as the data collection technique. Furthermore, "interview" method was used in $7.6 \%$ of the theses while "documentary literature review", which is the secondary data collection method, was used in $6.3 \%$ of them. "Observation" was not a preferred method by the researchers. Accordingly, it is seen that researchers mostly preferred quantitative methods in these studies conducted on business ethics.

Table 3. Findings Related to the Type of Studies, Methods Used and Data Collection Techniques

\begin{tabular}{lccc}
\hline \multicolumn{1}{c}{ Variable } & Category & Frequency & $\mathbf{\%}$ \\
\hline \multirow{3}{*}{ Type of Study } & Empirical & 74 & 91.4 \\
& Conceptual & 7 & 8.6 \\
& Theoretical & - & - \\
& Total & $\mathbf{8 1}$ & $\mathbf{1 0 0}$ \\
\hline \multirow{2}{*}{ Method Used } & Quantitative & 64 & 86.4 \\
& Qualitative & 5 & 6.8 \\
& Mixed & 5 & 6.8 \\
& Total & $\mathbf{7 4}$ & 100 \\
\hline \multirow{2}{*}{ Data Collection Technique } & Questionnaire & 68 & 86.1 \\
& Interview & 6 & 7.6 \\
& Observation & - & 5 \\
\end{tabular}

As shown in Table 4, 35.1\% of the studies examined did not include any information about sampling method. In addition, it was determined that non-probability sampling method was used in $29.7 \%$ of the studies and probability sampling methods were used in $25.7 \%$ of the studies. In $9.5 \%$ of the theses, all participants in the universe were reached by using total population sampling. Considering the sample preference, the most preferred sample by the researchers is "employees at every level "(40.5\%) while the sample "managers" $(23 \%)$ is the second most preferred sample group. Finally, bank, accounting, marketing, healthcare employees and academicians are the other sample groups preferred by the researchers. 
Table 4. Findings Related to Sampling Method and Sample Preference

\begin{tabular}{cccc}
\hline Variable & Category & Frequency & \% \\
\hline & Not Specified & 26 & 35.1 \\
Sampling Method & Non-Probability Sampling Methods & 22 & 29.7 \\
& Probability Sampling Methods & 19 & 25.7 \\
& Total Population Sampling & 7 & 9.5 \\
& Total & $\mathbf{7 4}$ & $\mathbf{1 0 0}$ \\
\hline & Employees at Every Level & 30 & 40.5 \\
Sample Preference & Managers & 17 & 23.0 \\
& Bank Employees & 10 & 13.5 \\
& Accounting Employees & 5 & 6.8 \\
& Marketing Employees & 3 & 4.1 \\
& Healthcare Employees & 2 & 2.7 \\
\hline
\end{tabular}

The findings obtained within the scope of the research showed that the survey method was used as data collection techniques in most of the theses. Therefore, it is important to know which scales were used in the theses. However, the analyses revealed that $32.4 \%$ of the theses did not include any information about the scale used. In $26.5 \%$ of the studies, it was determined that the scale which was created by the researchers as a result of the literature search was used. It is seen that in some of the other researches, Schwepker et al. (1997) - Ethical Climate Scale (7.4\%), Forsyth (1980) - Ethical Approach Scale (7.4\%), Neumann and Reichel (1979) - Business Ethics Attitude Scale (4\%) and Victor and Cullen ( 1988) - Ethical Climate Scale (7.4\%) were used. The other findings in Table 5 are related to the validity and reliability analyses of the scales used. According to the data obtained, the validity studies of almost half of the theses (48.6\%) were not conducted. On the other hand, it was detected that reliability analyses were performed in $78.4 \%$ of the studies.

Table 5. Findings Related to the Scales Used, Validity and Reliability Studies

\begin{tabular}{|c|c|c|c|}
\hline Variable & Category & Frequency & $\%$ \\
\hline \multirow{10}{*}{ Scale Used } & Not Specified & 22 & 32.4 \\
\hline & Created by the researcher with literature review & 18 & 26.5 \\
\hline & Schwepker et al. (1997) & 5 & 7.4 \\
\hline & Ethical Climate Scale & & \\
\hline & Forsyth (1980) & 5 & 7.4 \\
\hline & Ethical Approach Scale & & \\
\hline & Neumann and Reichel (1979) & 3 & 4.4 \\
\hline & Business Ethics Attitude Scale & & \\
\hline & $\begin{array}{l}\text { Victor and Cullen (1988) } \\
\text { Ethical Climate Scale }\end{array}$ & 3 & 4.4 \\
\hline & Total & 56 & 82.4 \\
\hline \multirow{3}{*}{ Validity Study } & Performed & 38 & 51.4 \\
\hline & Unperformed & 36 & 48.6 \\
\hline & Total & 74 & 100 \\
\hline \multirow{3}{*}{ Reliability Study } & Performed & 58 & 78.4 \\
\hline & Unperformed & 16 & 21.6 \\
\hline & Total & 74 & 100 \\
\hline
\end{tabular}

As seen in Table 6, "descriptive statistics" (67) was used the most in the theses. In addition, "Cronbach's alpha" (47), "Correlation" (41), "ANOVA" (38), "factor analysis (36), "t-test" (36) and "regression analysis" are the other most commonly used analyses, respectively. In this context, it is possible to say that researchers intensively use univariate and bivariate data analysis methods. 
Table 6. Findings Related to the Analyses

\begin{tabular}{|c|c|c|}
\hline Variable & Category & Frequency \\
\hline \multirow{8}{*}{ Analyses } & Descriptive Statistics & 67 \\
\hline & Cronbach's Alpha & 47 \\
\hline & Correlation Analysis & 41 \\
\hline & ANOVA & 38 \\
\hline & Factor Analysis & 36 \\
\hline & T-test & 36 \\
\hline & Regression & 25 \\
\hline & Total & 290 \\
\hline
\end{tabular}

According to the findings obtained within the scope of the question "Which variables are the most associated with the concept of business ethics?", "demographic characteristics" (41) category takes place on the top. In addition, the concept of business ethics was mostly handled with the concepts of "social responsibility" (14) "human resources management functions" (10) "job satisfaction" (8) "organizational commitment" (7) and "employee performance" (6), respectively. Moreover, the analyses performed show that business ethics is also searched with the concepts such as "leadership" (3) "ethical theories" (3) "organizational justice" (2), "organizational strategy" (2) and "workplace deviation behaviour" (2). When the findings obtained are taken into consideration, it can be stated that the concept of business ethics is often subjected to researches by being associated with organizational behaviour issues.

Table 7. Findings Related to the Variables Associated with Business Ethics and Dimensions Handled

\begin{tabular}{ccc}
\hline Variable & Category & Frequency \\
\hline & Demographic Characteristics & 41 \\
& Social Responsibility & 14 \\
Associated Variables & Human Resources Management Functions & 10 \\
& Job Satisfaction & 8 \\
& Organizational Commitment & 7 \\
& Employee Performance & 86 \\
\hline & Total & 48 \\
Dimensions Handled & Business Ethics Perception & 8 \\
& Business Ethics Principles & 7 \\
& Ethical Climate & 5 \\
& Unethical Behaviour & 4 \\
& Ethical Position Levels of Individuals & 3 \\
& Ethical Dilemmas & 75 \\
\hline
\end{tabular}

In Table 7, the findings regarding the dimensions that business ethics is frequently handled with are shown. In this context, it is seen that in more than half of the theses (48), the attitudes or perceptions of the participants towards business ethics are evaluated with a holistic perspective. In addition, in 8 theses, business ethics was subjected to researches within the frameworks of principles such as "justice, honesty, responsibility and tolerance". According to the other findings obtained, the concept of business ethics was mostly investigated with the dimensions of ethical climate (7), unethical behaviours (5), ethical position levels examining the participants' views on ethical values (4) and ethical dilemmas (3).

\section{Discussion}

Business ethics is a phenomenon that requires looking after the favour of all stakeholders that can be affected from the activities of the enterprise in addition to the primary objective of enterprises whose raison d'etre is to make profit. In this way, profit can be made more meaningful. Therefore, the effort to understand the concept of business ethics is an important field of study for researchers. Accordingly, business ethics, both in Turkey and in the world, is a subject that attracts much attention of researchers. In this direction, our study seeks the answer to "What is the current status of the studies on business ethics in the business literature of Turkey?" question. In this study, the postgraduate theses conducted in the field of business management in Turkey were examined with content analysis method in accordance with certain criteria. The theses were obtained from the access page of the Council of Higher Education Thesis Centre. In the search made with the business ethics/work ethics keywords, 81 theses, which were prepared in the field of business management and had access permission, were detected and analyzed within the scope of the study.

When the theses included in the study were evaluated within the context of the year of publication criterion, it was determined that the study frequency of the subject has increased significantly in recent years. In fact, it can 
be stated that the studies have increased by half in 2018 compared to 2017. This finding that we obtained is important due to various aspects. First of all, revealing the unethical activities of some of the enterprises globally operating in recent years shows that the loss of ethical value is a very important problem in the business life. The activities of the enterprises which endanger the health and safety of the society in order to gain more profit prove that business ethics is a part of the business world that should not be abandoned. Therefore, the need for ethical principles in the business world is increasing day by day. In this context, the significant increase in the number of postgraduate studies on business ethics in recent years can be considered as a step taken in the right direction in order to understand the phenomenon. Nevertheless, it needs to be highlighted that Turkey has been very late to take these steps compared to the world. Indeed, as also stated by Schwartz (2007), business ethics was an academic study area which had already become the subject of many conferences, books and courses at universities as of 1985 (DeGeorge, 1987:203). For this reason, it is possible to state that the researchers in Turkey has been late in terms of showing interest to the subject as an academic field when compared to the foreign literature.

The results of the analyses showed that in these studies emerging as a result of a belated interest, the researchers were particularly curious about whether there was a significant relationship between the employees' attitudes towards business ethics and demographic characteristics such as gender, age, education and tenure. Business ethics has also been heavily associated with the concepts included within the scope of positive organizational behaviour. Accordingly, it can be stated that researchers frequently focus on the potential of business ethics to create satisfied, high performance employees who have commitment to the organization and feel like themselves as the citizens of the organization. As mentioned earlier, enterprises are often criticized for using business ethics as a strategic tool that can be used to make more profits (Aasland, 2004). In this context, it will not be wrong to state that researchers are trying to provide new tools to enterprises that they can use in this direction and thus they justify such criticisms.

The analyses showed that the majority of the examined theses were "empirical" studies. No "theoretical" study, which could contribute to the deeper understanding of the concept by addressing business ethics within the context of philosophical foundations, was found. On the other hand, the findings of the study revealed that the quantitative method was used in the majority of the theses within the context of empirical study and survey method was used as the data collection tool. For this reason, it can be stated that the postgraduate studies conducted on business ethics in Turkey show parallelism with the foreign literature (Brand, 2009; McDonald, 2000; Crane, 1999; Cowton, 1998) and shape under the domination of positivist paradigm. Therefore, the criticisms brought about the formation of business ethics researches under positivist paradigm in the foreign literature gain validity. That is, business ethics is a complex, context-specific and abstruse phenomenon by its nature. Therefore, it is obvious that a data collection tool designed to achieve generally accepted results such as questionnaires will remain quite superficial when it comes to business ethics. As a matter of fact, it can be argued that qualitative research methods that enable access to much deeper data are much more compatible with the complex nature of business ethics (Crane, 1999; Cowton, 1998; Robertson, 1993). As a consequence, it is seen that it is not possible to evaluate the postgraduate theses conducted within the scope of business ethics in Turkey within the framework of the in-depth and rich-content studies paying attention to the context. On the contrary, these studies can be described as superficial studies ignoring the question "why" and failing to go beyond describing the current situation.

Finally, the research methods used in these studies shaped within the framework of the positivist paradigm should also be mentioned. As mentioned before, it was detected that almost half of the postgraduate theses did not provide information about the scales used, and the other part used scales obtained from the foreign literature and adapted into Turkish. Furthermore, it is seen that validity studies were not conducted in $48.6 \%$ of the theses. At this point, the suspicion whether the scales measured the facts they wanted to measure comes to the forefront. Accordingly, although studies conducted on business ethics in Turkey shape within the scope of positivist paradigm, it is possible to say that they have shortcomings in terms of fulfilling the requirements of the paradigm.

\section{References}

Aasland, D. G. (2004). On the ethics behind "business ethics". Journal of Business Ethics, 53, 3-8. https://doi.org/10.1023/B:BUSI.0000039395.63115.c2

Brand, V. (2009). Empirical business ethics research and paradigm analysis. Journal of Business Ethics, 86, 429-449. https://doi.org/10.1007/s10551-008-9856-3

Brand, V., \& Slater, A. (2003). Using a qualitative approach to gain insights into the business ethics 
experiences of Australian managers in China. Journal of Business Ethics, 45, 167-182. https://doi.org/10.1023/A:1024198904265

Brickley, J., Clifford, A., Smith Jr, W., \& Zimmerman, J. L. (2002). Business ethics and organizational architecture. Journal of Banking \& Finance, 26, 1821-1835. http://dx.doi.org/10.2139/ssrn.250947

Buckley, M. (2013). A constructivist approach to business ethics. Journal of Business Ethics, 117, 695-706. https://doi.org/10.1007/s10551-013-1719-x

Buckley, M. R., Beu, D. S., Frink, D. D., Howard, J. L., Berkson, H. M., Mobbs, T. A., \& Ferris, G. R. (2001). Ethical issues in human resources systems. Human Resource Management Review, 11, 11-29. https://doi.org/10.1016/S1053-4822(00)00038-3

Clegg, S., Kornberger, M., \& Rhodes, C. (2007). Business ethics as practice. British Journal of Management, 18, 107-122. https://doi.org/10.1111/j.1467-8551.2006.00493.x

Cowton, C. J. (1998). The use of secondary data in business ethics research. Journal of Business Ethics, 17, 423-434. https://doi.org/10.1023/A:1005730825103

Crane, A. (1999). Are you ethical? Please Tick yes $\square$ or no $\square$ On researching ethics in business organizations. Journal of Business Ethics, 20, 237-248. https://doi.org/10.1023/A:1005817414241

DeGeorge, R. T. (1987). The status of business ethics: Past and future. Journal of Business Ethics, 6, 201-211. https://doi.org/10.1007/BF00382865

Dimmock, M., \& Fisher, A. (2017). Ethics for A-level, in Business Ethics, Published by: Open Book Publishers, 143-154.

Fisher, J. (2004). Social Responsibility and ethics: Clarifying the concepts. Journal of Business Ethics, 52, 391-400. https://doi.org/10.1007/s10551-004-2545-y

Forsyth, D. R. (1980). A Taxonomy of ethical ideologies. Journal of Personality and Social Psychology, 39(1), 175-184. http://dx.doi.org/10.1037/0022-3514.39.1.175

Hoffman, W. M., \& Moore, J. M. (1982). What is business ethics? A reply to Peter Drucker. Journal of Business Ethics, 1, 293-300. https://doi.org/10.1007/BF00382818

Holme, C. (2008). Business ethics - Part one: Does it matter?. Industrial and Commercial Training, 40(5), 248-252. https://doi.org/10.1108/00197850810886487

Lewis, P. V. (1985). Defining 'business ethics': Like nailing jello to a wall. Journal of Business Ethics, 4(1985), 377-383. https://doi.org/10.1007/BF02388590

Lock, I., \& Seele, P. (2015). Quantitative Content analysis as a method for business ethics research. Business Ethics: A European Review, 24, 24-40. https://doi.org/10.1111/beer.12095

McDonald, G. (2000). Cross-cultural methodological issues in ethical research. Journal of Business Ethics, 27, 89-104. https://doi.org/10.1023/A:1006406505398

Neumann, Y., \& Reichel, A. (1979). The development of attitudes toward Business Ethics Questionnaire (ATBEQ): Concepts, dimensions, and relations to work values [Working Paper]. Ben Gurion University of Negev, Israel.

Randall, D. M., \& Gibson, A. M. (1990). Methodology in business ethics research: A review and critical assessment. Journal of Business Ethics, 9(6), 457-471. https://doi.org/10.1007/BF00382838

Robertson, D. C. (1993). Empiricism in business ethics: Suggested research directions. Journal of Business Ethics, 12(8), 585-599. https://doi.org/10.1007/BF01845895

Robin, D. (2009). Toward an applied meaning for ethics in business. Journal of Business Ethics, 89, 139-150. https://doi.org/10.1007/s10551-008-9990-y

Schwartz, M. (2007). The "Business ethics" of management theory", Journal of Management History, 13(1), 43-54. https://doi.org/10.1108/17511340710715160

Schwepker, C. H., Ferrel, O. C., \& Ingram, T. N. (1997). The influence of ethical climate and ethical conflict on role stress in the sales force. Journal of The Academy Of Marketing Science, 25(2), 99-108. https://doi.org/10.1007/BF02894345

Solomon, R. C. (2004). Aristotle, ethics and business organizations. Organization Studies, 25(6), 1021-1043. https://doi.org/10.1177/0170840604042409 
Treviño, L. K., \& Brown, M. E. (2004). Managing to be ethical: Debunking five business ethics myths. Academy of Management Executive, 18(2), 69-82. https://doi.org/10.5465/ame.2004.13837400

Victor, B., \& Cullen, J. (1988). The Organizational Bases of Ethical Work Climates. Administrative Sciences Quarterly, 33, 101-125. https://doi.org/10.1007/BF00412049

Vitell, S. J., \& Festervand, T. A. (1987). Business ethics: Conflicts, practices and beliefs of industrial executives. Journal of Business Ethics, 6, 111-122. https://doi.org/10.1007/BF00382024

Weavera, G. R., \& Treviño, L. K. (2001). The role of human resources in ethics/compliance management: A fairness perspective. Human Resource Management Review, 11, 113-134.

https://doi.org/10.1016/S1053-4822(00)00043-7

\section{Copyrights}

Copyright for this article is retained by the author(s), with first publication rights granted to the journal.

This is an open-access article distributed under the terms and conditions of the Creative Commons Attribution license (http://creativecommons.org/licenses/by/4.0/). 